\title{
Teknik Intervensi Nudge dengan Pendekatan Norm untuk Meningkatkan Perilaku Membaca Remaja
}

\author{
Anhar Dana Putra ${ }^{1 *}$, Dianti Endang Kusumawardhani' ${ }^{2}, \&$ Erita Narhetali ${ }^{2}$ \\ ${ }^{1}$ Prodi Manajemen Sumber Daya Manusia Aparatur, STIA LAN Makassar, Makassar \\ ${ }^{2}$ Fakultas Psikologi, Universitas Indonesia, Depok
}

\begin{abstract}
Abstrak
Penelitian ini merupakan penelitian terapan yang bertujuan untuk meningkatkan perilaku membaca pada remaja di Kabupaten Barru. Penelitian ini terbagi dalam dua tahap, yakni baseline study dan intervensi. Teori yang digunakan dalam baseline study adalah theory of planned behaviour. Berdasarkan hasil baseline study ditemukan bahwa faktor norma subjektif memiliki pengaruh yang paling signifikan terhadap intensi remaja untuk membaca buku $(\beta=0,247 p<0,05)$. Sementara itu, intervensi menerapkan teknik intervensi nudge dengan pendekatan norma. Intervensi diuji dengan independent $t$ test melalui metode eksperimen dengan rancangan post-test only control group design dengan jumlah sampel sebanyak 32 orang. Hasil eksperimen menunjukkan bahwa; partisipan yang mendapatkan pesan visual nudge dengan pendekatan norm membaca lebih lama dibandingkan partisipan dalam kelompok kontrol.
\end{abstract}

Kata kunci: perilaku membaca, remaja, theory of planned behavior, nudge, pesan norm

\begin{abstract}
This study is an applied research which aims to improve reading for pleasure behavior among adolescence in Barru Regency. This study was conducted in two phases: baseline study and intervention. We utilized theory of planned behavior as a main theory for baseline study. The result of baseline study showed that the most significant variable in predicting intention to read for pleasure among adolescence was norma subjektif towards reading for pleasure $(\beta=0.247 p<0.05)$. This study applied nudge with norm approach as the intervention to improve reading for pleasure. For the main intervention, we conducted a post-test only control group design experiment with $\mathrm{N}=$ 32 participants. The effect of intervention was measured with independent samples $t$ test. The experiment results showed that; participants who were given nudge with norm message read longer than participants who were not.
\end{abstract}

Keywords: reading for pleasure, adolescent, theory of planned behavior, nudge, norm message

\section{Pendahuluan}

Hasil penelitian Perpustakaan Nasional tahun 2017 menunjukkan bahwa saat ini minat baca masyarakat di Indonesia masih tergolong rendah (Nadlir, 2018). Menurut studi yang dilakukan Central Connecticut State University pada tahun 2016 tentang Most Literate Nations In The World, indeks kegemaran membaca Indonesia hanya berkisar 0,01 yang mana berarti hanya satu orang dari setiap 10.000 orang Indonesia yang memiliki minat baca serius (Rossa, 2018). Indikasi tersebut juga diperkuat oleh data yang dirilis oleh Badan Pusat Statistik (BPS) pada tahun 2006 bahwa masyarakat Indonesia lebih suka menghabiskan waktu dengan menonton televisi mendengarkan radio daripada membaca (Hapsari, 2009).
Tinggi rendahnya budaya membaca masyarakat juga dapat tercermin dari seberapa banyak orangyang berkunjung ke perpustakaan. Berdasarkan data Pengunjung Perpustakaan di Indonesia yang dilansir oleh Handayani (2008), total seluruh pengunjung perpustakaan dari setiap daerah setiap tahunnya dari tahun 2005 hingga 2007 hanya sekitar 2\% dari jumlah seluruh penduduk Indonesia. Jika dilihat secara khusus pada setiap daerah berdasarkan persentase tersebut, maka dapat disimpulkan, jumlah pengunjung perpustakaan di setiap daerah rata-rata hanya sebesar $2 \%$ dari total jumlah penduduk di daerah masing-masing. Salah satu daerah rural di Indonesia yang memiliki masalah budaya baca adalah Kabupaten Barru yang terletak di Provinsi Sulawesi Selatan. Jika data sebelumnya menunjukkan bahwa jumlah pengunjung perpustakaan di setiap 
daerah rata-rata sebesar $2 \%$ dari total jumlah penduduk, di Kabupaten Barru pengunjung perpustakaan bahkan kurang dari 1\% dari total penduduk (Perpustakaan Nasional, 2015).

Masalah rendahnya budaya membaca masyarakat di Kabupaten Barru juga terlihat dari studi awal yang kami lakukan pada bulan April 2016 selama satu minggu melalui survei secara online menggunakan Google Form dan disebarkan melalui media jejaring sosial seperti Facebook, Line dan WhatsApp kepada 52 orang masyarakat dengan rentang usia 13 - 35 tahun di Kabupaten Barru. Hasil survei tersebut menunjukkan bahwa masyarakat di Kabupaten Barru sebagian besar (53\%) lebih memilih menghabiskan waktu bermain gadget di waktu senggang, dibanding membaca buku. Terlihat dari data bahwa hanya kurang dari sepertiga $(27 \%)$ responden yang menghabiskan waktu dengan membaca buku di waktu senggang.

Temuan-temuan tersebut tentu saja merupakan fenomena yang mencemaskan sebab kegiatan membaca adalah kegiatan yang sangat penting bagi perkembangan sosial dan budaya dalam masyarakat (Moore, Bean, Birdyshaw, \& Rycik, 1999). Dengan berinteraksi lebih sering dengan bacaan, seseorang dapat mengembangkan keterampilan-keterampilan untuk menjadi warga negara yang beradab dan berbudaya. Alvermann (2001) bahkan menemukan bahwa terdapat hubungan positif antara perilaku membaca dengan prestasi seseorang di sekolah, khususnya yang berkaitan dengan tugas-tugas memahami bacaan. Di sisi lain, seseorang yang jarang atau tidak pernah membaca di luar sekolah, secara sosial gagal memperolah aset-aset dan pengetahuanpengetahuan penting.

Merujuk pada Theory of planned behaviour oleh Fishbein dan Ajzen (2005), perilaku membaca buku juga dapat dijelaskan oleh faktor intensi membaca buku. Fishbein dan Ajzen menyatakan bahwa intensi adalah suatu tekad yang bulat untuk melakukan suatu perilaku tertentu atau menghasilkan suatu keadaan tertentu di masa depan. Intensi merupakan sebuah faktor psikologis yang berada ditengah-tengah antara sikap dan perilaku, dengan kata lain perilaku membaca tidak akan muncul tanpa didahului oleh intensi membaca buku meskipun sikap terhadap perilaku tersebut sangat kuat. Terdapat tiga faktor yang dapat menyebabkan munculnya intensi, yang akhirnya berpengaruh terhadap munculnya suatu perilaku yakni: sikap terhadap perilaku tertentu (attitude towards behaviour), norma subjektif, dan perceived behavior control.

Faktor kesulitan akses untuk mendapatkan buku bacaan yang dialami masyarakat, khususnya remaja di Kabupaten Barru bisa saja menyebabkan perceived behaviour control mereka terhadap perilaku membaca rendah. Perceived Behavioural Control terhadap perilaku membaca merujuk pada suatu persepsi seseorang tentang apakah suatu perilaku berada di bawah kendalinya (Ajzen, 1991). Seseorang akan memiliki intensi yang lemah untuk melakukan sesuatu jika orang tersebut menganggap bahwa sumber daya atau kesempatan untuk melakukannya tidak tersedia, betapa pun orang tersebut memiliki sikap yang positif dan meyakini bahwa orang-orang yang berpengaruh bagi orang tersebut mendukung-nya untuk membaca buku. Jika perceived behavioural control dimasukkan ke dalam konteks perilaku membaca buku, maka seseorang akan memiliki intensi untuk membaca buku yang lemah jika orang tersebut beranggapan bahwa dirinya tidak memiliki sumber daya atau kesempatan untuk membaca buku. Dengan begitu, mereka akan cenderung menganggap bahwa perilaku membaca adalah perilaku yang sulit untuk mereka lakukan (Ajzen, 1991).

Sebagian besar masyarakat, khususnya remaja di Kabupaten Barru tidak memilih kegiatan membaca buku sebagai kegiatan yang mereka lakukan di waktu senggang, juga bisa saja disebabkan oleh dua faktor lainnya, yakni sikap dan norma subjektif terhadap perilaku membaca, yang negatif. Fishbein dan Ajzen (2005) menjelaskan bahwa sikap merupakan suatu penilaian menyeluruh yang memungkinkan seseorang untuk merespon suatu obyek tertentu atau dengan kata lain sikap merupakan penilaian evaluatif yang berkaitan dengan satu hal tertentu, baik itu orang, keadaan atau suatu peristiwa tertentu. Berdasarkan uraian tersebut dapat disimpulkan bahwa sikap terhadap perilaku membaca merupakan seperangkat penilaian pribadi yang dimiliki seseorang terhadap perilaku membaca berdasarkan pengetahuan dan keyakinan personal, seperti apakah perilaku membaca itu menyenangkan atau tidak menyenangkan, apakah seseorang menyukai atau tidak menyukai kegiatan membaca, serta apakah perilaku membaca menguntungkan atau tidak menguntungkan.

Sementara norma subjektif menurut Fishbein dan Ajzen (2005) merupakan gabungan antara normative belief dan motivation to comply. Normative beliefs merupakan keyakinan seseorang tentang sepakat atau tidak-sepakatnya orang-orang yang berpengaruh bagi seseorang, atau sering kali disebut dengan istilah significant others seperti orang tua, pasangan, kerabat, teman dekat, atau pimpinan di tempat kerja terhadap suatu perilaku tertentu. Motivation to comply merupakan keinginan untuk mengikuti atau menuruti dukungan significant others tersebut. Berdasarkan uraian-uraian tersebut dapat disimpulkan bahwa norma subjektif terhadap perilaku membaca merujuk kepada seperangkat penilaian, keyakinan atau persepsi pribadi tentang tekanan atau dukungan sosial (teman, keluarga, dan lingkungan) terhadap perilaku membaca dan seberapa besar orang tersebut mau menuruti persepsi terhadap dukungan sosial tersebut untuk memunculkan perilaku membaca

Berbagai upaya telah dilakukan oleh berbagai pihak termasuk pemerintah, Lembaga swadaya masyarakat dan para peneliti dan pegiat literasi untuk menumbuhkan perilaku membaca masyarakat di Indonesia, namun upaya-upaya tersebut masih belum dapat dikatakan berjalan efektif. Penelitian ini bertujuan untuk memberikan alternatif upaya 
intervensi yang dapat dilakukan untuk meningkatkan perilaku membaca masyarakat. Penelitian ini bertujuan untuk menguji teknik intervensi Nudge dalam mengatasi masalah perilaku membaca di Indonesia, khususnya di Kabupaten Barru.

Teknik intervensi Nudge dianggap paling tepat diterapkan untuk meningkatkan perilaku membaca remaja di Kabupaten Barru sebab teknik intervensi Nudge menurut studi literatur yang dilakukan oleh Egan (2013) menemukan bahwa Teknik intervensi Nudge telah berbukti berhasil melakukan perubahan perilaku masyarakat dalam berbagai konteks, seperti dalam konteks perilaku hidup sehat antara lain; mengurangi konsumsi alkohol dan rokok, dan meningkatkan konsumsi makanan sehat. Juga dalam konteks lain, seperti meningkatkan perilaku membayar pajak, menghemat pemakaian energi, serta perilaku berdonasi.

Teknik intervensi Nudge pertama kali dikembangkan oleh Pemenang Nobel ekonomi tahun 2017 Richard Thaler bersama koleganya Cass Sunstein lewat bukunya berjudul Nudge: Improving Decision About Health, Wealth and Happiness. Thaler dan Sunstein (2008) menjelaskan bahwa Nudge merupakan teknik perubahan perilaku yang memiliki prinsip libertarian paternalism yang mana berarti intervensi dilakukan secara halus, tidak bersifat memaksa atau mengatur, melainkan memberi-kan kebebasan kepada target perubahan perilaku untuk mengambil keputusan sendiri atas perilakunya. Prinsip dan tipikal dari teknik intervensi nudge tersebut dianggap sesuai dengan karakteristik remaja yang menjadi target intervensi dalam penelitian ini, yang mana menurut Santrock (2003) menyukai kebebasan dan tidak suka didikte dan diperintah.

Hansen (2016) dalam studinya kemudian melengkapi definisi dari nudge sebagai sebuah percobaan untuk memengaruhi penilaian, keputusan atau pilihan serta perilaku seseorang dengan cara memanfaatkan adanya keterbatasan-keterbatasan kognitif, bias-bias, rutinitas, dan kebiasaan-kebiasaan serta adanya kecenderungan manusia untuk mengambil keputusan secara tidak rasional, sebagai bagian utama dalam percobaan tersebut. Oleh karena itu, nudge merupakan sebuah strategi memengaruhi perilaku tanpa melakukan pelarangan atau pembatasan, tanpa menambahkan pilihan-pilihan rasional, tanpa mengubah insentif (seperti memberikan hukuman atau hadiah), serta tanpa memaparkan informasi faktual dan argumentasiargumentasi persuasif.

Salah satu studi yang dianggap cukup berhasil dalam menerapkan Teknik intervensi Nudge menggunakan salah satu pendekatan yang telah disebutkan sebelumnya adalah studi yang dilakukan Schultz, Nolan, Cialdini, Goldstein, dan Griskevicius (2007). Studi tersebut menerapkan intervensi nudge dengan pendekatan norma sosial. Dalam studi tersebut ditemukan bahwa dengan memaparkan pesan yang berisi informasi tentang norma (pemakaian listrik tetangganya) kepada seseorang, terbukti dapat mengurangi pemakaian listrik orang tersebut.
Pada studi lain, Schultz, Khazian dan Zaleski (2008) melakukan sebuah eksperimen untuk menguji teknik intervensi Nudge menggunakan pesan norma untuk mendorong pemakaian ulang handuk pada pelanggan hotel untuk menghemat energi. Kelompok kontrol pada eksperimen tersebut dipaparkan pesan berisi tulisan "This hotel has initiated a conservation program." (Hotel ini sedang menjalankan program konservasi). Sementara pada kelompok eksperimen, partisipan diberikan pesan berisi tulisan "Nearly 75\% of hotel guests choose to reuse their towels each day. To support our guests who want to conserve, this hotel has initiated a conservation program". (Hampir 75\% pelanggan hotel ini memakai handuk berulang kali setiap hari untuk mendukung program konservasi yang sedang dijalankan hotel ini). Schultz dkk. (2008) dalam studi tersebut menemukan bahwa terdapat perubahan perilaku yang signifikan pada partisipan di kelompok eksperimen.

Studi lain yang menerapkan intervensi Nudge dengan pemberian pesan norma juga dilakukan oleh Aldrovandi, Brown, dan Wood, (2015) pada konteks yang berbeda yakni perilaku membeli makanan sehat, membuktikan bahwa apabila diberitahukan tentang perilaku membeli makanan sehat orang-orang di sekitarnya, seseorang dapat terpengaruh untuk ikut membeli makanan sehat. Studi-studi tersebut di atas menjadi dasar membangun hipotesis untuk penelitian ini. Hipotesis dalam intervensi pemberian intervensi nudge berupa pesan visual dengan pendekatan norma sosial berpengaruh signifikan kepada peningkatan perilaku membaca remaja di Kabupaten Barru.

Penelitian ini dilakukan dalam dua tahap penelitian, yakni baseline study dan studi intervensi. Tahap penelitian pertama, yakni baseline study merupakan tahap penelitian untuk menguji seberapa signifikan ketiga faktor penyebab munculnya intensi membaca buku berpengaruh terhadap munculnya perilaku membaca. Mengetahui seberapa besar signifikansi ketiga faktor munculnya intensi membaca buku merupakan langkah yang sangat penting guna mendukung hipotesis penelitian intervensi.

\section{Baseline Study}

\section{Metode Penelitian}

\section{Partisipan, Desain dan Prosedur}

Baseline study dilaksanakan dengan tujuan untuk mendapatkan data dan gambaran pengetahuan mengenai perilaku membaca pada masyarakat di Kabupaten Barru, termasuk menguji faktor mana di antara sikap, norma subjektif, dan perceived behavioural control yang paling signifikan memprediksi perilaku membaca. Perilaku membaca dalam penelitian ini merujuk pada perilaku membaca sebagai hiburan atau kegiatan di waktu senggang. Dalam konteks remaja sebagai siswa, perilaku 
membaca merujuk pada perilaku membaca buku di luar sekolah. Perilaku membaca berdasarkan pengertian tersebut, dalam beberapa literatur ilmiah dikenal dengan istilah yang berbeda-beda, seperti recreational reading, reading for pleasure, independent reading ataupun voluntary reading. Baseline study dilakukan dengan dua tahap, tahap elisitasi dan tahap baseline study. Tahap elisitasi adalah tahap dimana keyakinan-keyakinan yang dimiliki (salient beliefs) oleh masyarakat di Kabupaten Barru selama ini tentang perilaku membaca buku digali kemudian dikonversi menjadi item untuk alat ukur berbentuk kuesioner yang akan digunakan pada tahap baseline study.

Tahap baseline bertujuan untuk mengukur seberapa berpengaruh faktor-faktor tersebut terhadap munculnya intensi membaca buku pada masyarakat di Kabupaten Barru. Pengukuran faktor-faktor tersebut akan dilakukan dengan menyebarkan kuesioner yang berisi item hasil konversi elisitasi kepada masyarakat Kabupaten Barru yang dipilih menggunakan teknik purposive sampling. Baseline study dilakukan pada tanggal 20 Oktober 2016 di tiga sekolah yang ada di Kabupaten Barru, yakni SMAN 1 Barru, SMAN 2 Barru, dan SMKN 1 Barru. Responden diambil dari masing-masing 1 kelas di kelas 3, 2 dan 1 di masingmasing sekolah, dengan total 205 orang responden. Analisis statistik baseline study dilakukan dengan regresi linear berganda untuk menguji setiap faktor mana yang paling signifikan memengaruhi perilaku membaca.

\section{Teknik Analisis dan Hasil Penelitian}

Untuk mengidentifikasi faktor mana yang paling signifikan di antara tiga faktor yang memengaruhi intensi menamatkan setidaknya satu judul buku dalam sebulan dapat dilihat dengan menggunakan uji koefisien regresi linier berganda. Hasil uji koefisien regresi linier berganda menunjukkan bahwa faktor sikap terhadap perilaku membaca dan faktor norma subjektif memiliki pengaruh yang signifikan terhadap intensi membaca buku dengan nilai koefisien beta masing-masing sebesar 0,199 dan 0, 247, dengan nilai $p<0,05$. Namun di antara variabel keduanya, variabel independen yang paling signifikan memengaruhi variabel intensi menamatkan setidaknya satu judul buku dalam sebulan ke depan pada remaja di Kabupaten Barru adalah variabel norma subjektif. Dengan hasil ini, dapat disimpulkan bahwa rancangan intervensi yang paling efektif untuk meningkatkan perilaku menamatkan setidaknya satu judul buku dalam sebulan pada remaja di Kabupaten Barru adalah intervensi pada variabel norma subjektif.

\section{Diskusi}

Berdasarkan hasil uji koefisien linear berganda ditemukan variabel norma subjektif merupakan variabel independen yang paling signifikan memengaruhi variabel intensi menamatkan setidaknya satu judul buku dalam sebulan ke depan pada remaja di Kabupaten Barru, dengan nilai koefisien beta yang paling besar di antara ketiga variabel independen, yakni sebesar 0,247, dengan nilai p lebih kecil dari koefisien alpha $5 \%$, yakni 0,001 $<0,05$. Menurut Rivis dan Sheeran (2003), norma subjektif merupakan suatu belief (keyakinan) yang dimiliki oleh individu tentang seberapa besar orangorang terdekat atau yang dianggap penting (signifcant others) di sekitar mereka mengharapkan atau tidak mengharapkan individu yang dimaksud untuk melakukan atau tidak melakukan suatu perilaku dan seberapa besar individu yang dimaksud ingin menuruti harapan orang-orang tersebut untuk melakukan perilaku yang dimaksud. Dari hasil elisitasi ditemukan bahwa orang-orang terdekat atau yang dianggap penting (significant others) oleh remaja di Kabupaten Barru dalam menentukan intensi mereka untuk menamatkan setidaknya satu judul buku dalam sebulan adalah Orang Tua, Guru, Kakak/Adik, dan sahabat atau teman sepergaulan.

Besarnya pengaruh norma subjektif terhadap intensi menamatkan satu judul buku dalam sebulan pada remaja di Kabupaten Barru bisa saja karena remaja di Kabupaten Barru memang lebih banyak menghabiskan waktu bersama guru-guru mereka di sekolah, teman sepergaulan di luar sekolah dan orang tua di rumah. Kebiasaan orang-orang terdekat tersebut akan dipersepsikan sebagai suatu norma yang dapat memengaruhi mereka untuk menerapkan kebiasaan yang serupa. Hal tersebut diperkuat oleh Terry dan Hogg (2000) dalam studinya yang menyimpulkan bahwa orang-orang akan merasa sangat terdorong untuk melakukan sesuatu jika mereka meyakini bahwa orang-orang terdekatnya atau orang-orang dalam kelompoknya juga melakukan hal yang sama. Terlebih lagi ditunjang oleh kultur masyarakat di Kabupaten Barru yang secara umum diketahui memiliki pola perilaku dan kebiasaan yang cenderung seragam, kohesif dan memiliki konformitas yang tinggi, sehingga memperbesar peluang bagi para remaja di Kabupaten Barru untuk menyesuaikan diri dengan orang-orang di lingkungan terdekatnya.

\section{Studi Intervensi}

\section{Metode Penelitian}

Perilaku membaca dalam penelitian ini merujuk pada perilaku membaca sebagai hiburan atau kegiatan di waktu senggang atau dalam beberapa literatur ilmiah dikenal dengan istilah yang berbeda-beda, seperti recreational reading, reading for pleasure, independent reading ataupun voluntary reading. Istilah reading for pleasure sendiri menurut Clark and Rumbold (2006) merupakan kegiatan membaca yang dilakukan atas kehendak sendiri untuk mencari hiburan atau bersenang-senang. Terdapat beberapa dimensi dalam perilaku membaca, 
yakni frekuensi membaca, durasi membaca dan jumlah halaman yang dibaca. Perilaku membaca dalam penelitian ini dioperasionalkan terbatas hanya pada dimensi durasi membaca saja. Hal tersebut didasarkan pada Hasil studi Wu dan Samuels (2004) pada siswa sekolah menengah atas di Amerika yang menemukan bahwa durasi membaca berpengaruh terhadap produktivitas dalam membaca. Partisipan yang menghabiskan waktu 40 menit setiap hari membaca buku, lebih mudah untuk memahami katakata yang sulit dalam teks dibandingkan dengan partisipan yang tidak menghabiskan waktu 40 menit setiap hari membaca buku. Semakin mudah seseorang memahami teks semakin tinggi kemungkinan seseorang memperoleh sesuatu dari teks tersebut kemudian menikmatinya.

\section{Desain}

Efektivitas intervensi diuji dengan menggunakan metode eksperimen dengan desain two-group, post-test only randomized design.

\section{Partisipan}

Penelitian eksperimen ini memiliki sampel sebanyak 32 orang remaja (SMA Kelas 1-3) yang berdomisili di Kabupaten Barru. Partisipan dibagi menjadi dua kelompok secara acak, yakni kelompok eksperimen dan kelompok kontrol masing-masing 16 orang.

\section{Prosedur}

Intervensi berlangsung selama satu minggu. Dimulai pada hari Minggu tanggal 27 November 2016 hingga Minggu 4 Desember 2016. Pertemuan pertama berlangsung pada Hari Sabtu 26 November 2016 untuk mengumpulkan partisipan dan menjelaskan prosedur penelitian. Setelah semua partisipan mengerti prosedurnya dan menandatangani lembar informed consent, peserta kemudian diminta untuk memilih satu judul buku dari buku-buku yang telah disediakan, yang nantinya akan dibawa pulang kemudian dibaca dalam kurun waktu satu minggu di rumah masing-masing. Pertimbangan waktu satu minggu didasarkan pada hasil baseline dimana terdapat $44,8 \%$ orang responden yang mengaku membutuhkan waktu setidaknya 1 minggu untuk menamatkan satu judul buku. Setelah pertemuan pertama selesai partisipan diberikan semacam kartu kontrol untuk mencatat durasi membaca partisipan. Setiap kali partisipan membaca dalam kurun waktu tersebut, partisipan diminta mencatat durasinya dalam kartu kontrol.

Dalam kurun waktu satu minggu, partisipan di kelompok eksperimen mendapatkan intervensi berupa pemberian pesan visual yang telah dirancang sebelumnya, melalui aplikasi chat Line dan Facebook Messenger yang sebelumnya sudah dicatat id accountnya nya pada pertemuan pertama. Intervensi nudge berupa pemberian pesan visual norma sosial dilakukan sebanyak 3 kali dalam kurun waktu seminggu yakni pada hari Senin 28 November, rabu 30 November dan Jumat 2 Desember 2016. Hal tersebut didasarkan oleh pertimbangan peneliti sendiri bahwa pemberian intervensi berupa pesan visual tidak akan cukup jika hanya dilakukan sekali dalam seminggu, misalnya pada hari senin saja atau pada hari rabu saja.

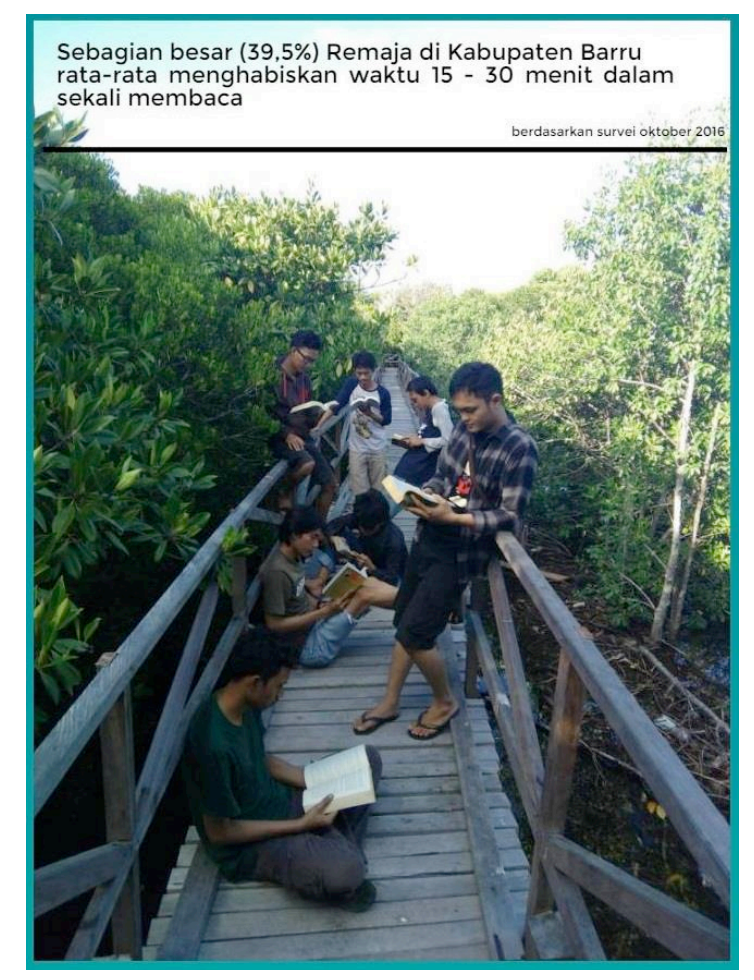

Gambar 1. Intervensi Nudge berupa Pesan Visual berisi informasi tentang Perilaku Membaca orangorang dari kelompok usia yang sama(Social Norms)

Pemberian pesan visual setiap harinya dilakukan pada pukul 15.00-16.00 dengan pertimbangan jam pulang sekolah, mengingat seluruh partisipan merupakan siswa sekolah menengah atas yang tidak diperbolehkan membawa handphone ke sekolah. Setelah satu minggu, seluruh partisipan dari kedua kelompok kemudian dikumpulkan kembali pada pertemuan kedua pada hari Minggu 4 Desember 2016. Pada pertemuan kedua ini para partisipan diminta mengumpulkan masing-masing kartu kontrol yang telah diisi selama kurun waktu satu minggu. Setelah peneliti mengumpulkan seluruh kartu kontrol dari partisipan, peneliti kemudian membagi-bagikan suvenir berupa gantungan kunci yang telah disiapkan sebagai ucapan terima kasih telah bersedia menjadi partisipan.

\section{Teknik Analisis}

Pengukuran intervensi dilakukan dengan metode kuantitatif. Hasil evaluasi secara kuantitatif diperoleh dari hasil perbandingan rata-rata hasil 
durasi membaca, yang diperoleh oleh kelompok kontrol dan hasil yang diperoleh oleh kelompok eksperimen. Pada tahap ini analisis signifikansi perbedaan di antara dua kelompok dilakukan dengan pengukuran statistik dengan bantuan SPSS versi 17.

\section{Hasil Penelitian}

Berdasarkan uji normalitas dan homogenitas yang telah dilakukan, data frekuensi membaca, durasi membaca serta jumlah halaman antara kelompok eksperimen dan kelompok kontrol diketahui berdistribusi normal dan homogen. Oleh karena itu pengujian hipotesis dengan menggunakan independent sample $t$ test sudah memenuhi syarat untuk dilakukan.

Hasil eksperimen menunjukkan bahwa kelompok eksperimen memiliki nilai rata-rata sebesar 30,41 menit per satu kali membaca sementara kelompok kontrol memiliki nilai rata-rata durasi membaca sebesar 19,51 menit per satu kali membaca dan norma rata-rata remaja sebesar 28 menit. Berdasarkan hasil tersebut dapat disimpulkan bahwa kelompok eksperimen memiliki nilai rata-rata durasi membaca per satu kali kesempatan membaca yang lebih tinggi daripada kelompok kontrol.

Berdasarkan hasil perhitungan uji independent sample t-test pada aspek durasi membaca diperoleh $\mathrm{t}$ $(30)=2,461, p=0,02$. Berdasarkan hasil perhitungan tersebut dapat disimpulkan hasil uji hipotesis bahwa ada perbedaan durasi per satu kali kesempatan membaca yang signifikan antara remaja kelompok eksperimen. Dengan kata lain, pemberian intervensi nudge berupa pesan visual dengan pendekatan norm berpengaruh signifikan kepada peningkatan durasi membaca.

\section{Diskusi}

Efektivitas dari intervensi pemberian pesan visual untuk meningkatkan perilaku membaca akan disimpulkan dari perbedaan atau perbandingan nilai rata-rata partisipan antara kedua kelompok pada aspek durasi membaca. Terdapat banyak sekali faktor yang dapat memengaruhi seseorang untuk mewujudkan perilaku membaca buku. Dengan menyadari hal tersebut, penelitian ini berupaya untuk mengontrol faktor-faktor tersebut sehingga faktor yang bisa saja memengaruhi munculnya tidak menjadi variabel pengganggu. Tentu peneliti memiliki keterbatasan untuk mengontrol seluruh perilaku membaca, sehingga peneliti hanya mengontrol faktor-faktor yang terjangkau saja seperti; buku-buku yang disediakan untuk dibaca oleh partisipan di kedua kelompok, merupakan buku dibaca oleh remaja di Kabupaten Barru merupakan novel yang dijamin merupakan jenis buku yang mudah dan dapat dibaca atau bahkan ditamatkan dalam waktu satu minggu. Berdasarkan data tambahan yang diperoleh ditemukan bahwa jenis buku yang mudah dengan

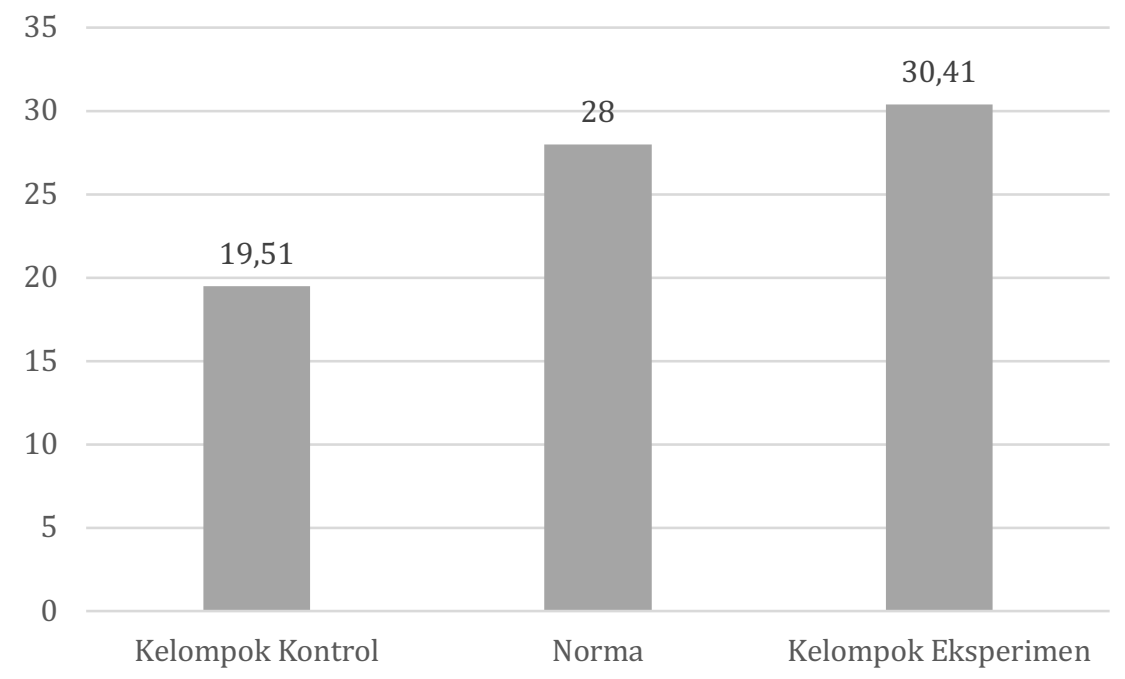

Gambar 2. Perbandingan Rata-Rata Durasi Per Satu Kali Kesempatan Membaca antara Kedua Kelompok dan Norma (Dalam Menit)

Tabel 1. Uji Hipotesis Independent Sample T-Test

\begin{tabular}{llllll}
\hline & Kelompok & & & & \\
\hline & Eksperimen & Kontrol & $t$ & sig. \\
\hline Durasi & 30,42 & 19,51 & 2,461 & 30 & $0,02^{*}$ \\
Membaca & $(13,714)$ & $(11,235)$ & & $(28,882)$ & \\
\hline
\end{tabular}


ketebalan rata-rata kurang lebih 200 hingga 300 halaman. Sehingga dapat diasumsikan bahwa jenis buku dan jumlah halaman memiliki kondisi yang setara di antara kedua kelompok. Faktor lain yang juga dikontrol dalam penelitian ini adalah kesempatan memilih buku pilihan sendiri. Clark dan Phythian-Sence (2018) menyimpulkan dalam studinya bahwa faktor yang sangat kuat berhubungan dengan meningkatnya kegemaran perilaku membaca remaja adalah kesempatan memilih buku pilihan sendiri. Seseorang akan lebih tertarik untuk membaca sebuah buku jika ia sendiri yang memilih buku tersebut untuk dibaca.

Atas dasar hasil studi tersebut, partisipan dari kedua kelompok kemudian diberikan kesempatan memilih buku pilihan sendiri untuk memastikan seluruh partisipan, baik di kelompok eksperimen ataupun di kelompok kontrol, membawa pulang buku yang mereka pilih sendiri dan merupakan buku yang benar-benar membuat mereka tertarik. Faktor-faktor tersebut berupaya dikontrol dalam penelitian agar kondisi antara kelompok eksperimen dan kelompok kontrol menjadi setara, sehingga diharapkan satusatunya variabel pembeda antara kelompok kontrol dan kelompok eksperimen dalam mewujudkan perilaku membaca hanyalah intervensi pesan visual yang diberikan.

Berdasarkan hasil penelitian eksperimen yang telah dilakukan kemudian ditemukan kesimpulan bahwa teknik intervensi nudge berupa pemberian pesan visual dengan pendekatan social norm yang diterapkan dalam eksperimen, berpengaruh signifikan terhadap peningkatan durasi membaca. Keberhasilan intervensi nudge berupa pemberian pesan visual dengan pendekatan norma sosial dalam meningkatkan durasi membaca partisipan di kelompok eksperimen, mendukung temuan-temuan studi sebelumnya yang menyatakan bahwa pendekatan norma sosial memang terbukti efektif dalam mengubah perilaku (Chern, 2017). Hasil eksperimen ini juga didukung oleh penjelasan Berkowitz (2004) dalam tinjauannya terhadap studi-studi tentang social norm theory, bahwa peer memiliki pengaruh yang jauh lebih besar terhadap perilaku seseorang daripada faktor-faktor lain seperti faktor biologis, kepribadian, keturunan, agama serta budaya.

Peer yang dimaksud dalam penelitian ini merupakan significant others yang dimaksud dalam tahap elisitasi pada Baseline Study, yakni temanteman sebaya responden. Pengaruh peer tersebut terwujud dalam bentuk persepsi responden terhadap apa yang dilakukan atau tidak dilakukan, serta apa yang didukung atau tidak didukung oleh teman sebayanya. Semakin seseorang memersepsikan bahwa peer-nya sering melakukan sesuatu atau mendukung suatu perilaku, maka semakin besar pula kemungkinan orang tersebut melakukan atau mendukung perilaku yang sama (Berkowitz, 2004).

Dalam Teori Social Norms, seseorang bisa saja salah dalam mempersepsikan apa yang diyakini dan dilakukan oleh peernya, karena sifatnya yang subjektif dan tidak selalu sesuai dengan kondisi aktual (Miller \& McFarland, 1991). Pemberian intervensi nudge berupa pesan visual norma sosial merupakan metode persuasi tidak langsung untuk memaparkan partisipan di kelompok eksperimen dengan informasi tentang kondisi aktual perilaku membaca remaja yang merupakan peer dari mereka guna mengatasi masalah kesalahan persepsi tersebut, sehingga diasumsikan responden dapat mengubah perilakunya dengan mengikuti kondisi aktual tersebut (Chern, 2017). Dari hasil eksperimen yang dilakukan, terbukti partisipan yang terpapar dengan pesan visual yang memuat informasi aktual tentang perilaku membaca remaja di Kabupaten Barru membaca lebih lama daripada partisipan yang tidak terpapar dengan pesan visual tersebut.

\section{Kesimpulan}

Penelitian menunjukkan bahwa terdapat perbedaan yang signifikan antara durasi membaca per satu kali kesempatan membaca di kelompok eksperimen dengan durasi per satu kali kesempatan membaca pada remaja di kelompok kontrol.

\section{Keterbatasan dan Saran}

Hasil Penelitian ini dapat melengkapi deretan panjang daftar upaya yang dapat dilakukan untuk meningkatkan perilaku membaca masyarakat di Indonesia. Sekalipun sampel yang diuji pada intervensi ini cukup sedikit sehingga kurang cukup untuk melakukan generalisasi terhadap seluruh remaja di Kabupaten Barru, hasil penelitian ini dapat menjadi acuan untuk melakukan replikasi penelitian yang sama dengan jumlah sampel yang lebih besar atau dengan konteks, lokasi, atau variasi rancangan yang berbeda. Penerapan teknik nudge dengan pendekatan norma pada konteks perilaku membaca juga sangat jarang bahkan mungkin belum pernah dilakukan. Penelitian ini bisa saja menjadi bukti, bahwa Teknik intervensi nudge dengan pendekatan norma juga dapat bermanfaat untuk diterapkan pada konteks-konteks lain, baik itu pada perilaku berisiko, masalah kesehatan, maupun isu kekerasan dan radikalisme.

Hasil penelitian mengusulkan beberapa rekomendasi untuk berbagai pihak. Data tentang perilaku membaca di berbagai daerah di Indonesia masih sangat minim. Oleh karena itu diperlukan penelitian dan survei yang lebih sering dan pro-aktif dan upaya dokumentasi yang baik oleh akademisi, aktivis literasi, dan pemerintah untuk memperkaya data mengenai perilaku membaca di Indonesia, khususnya di kota kecil atau daerah-daerah (rural area). Bagi para akademisi yang tertarik untuk meneliti perilaku membaca remaja di Kabupaten Barru, sangat dibutuhkan replikasi penelitian tentang pengaruh nudge dengan pendekatan norm dengan jumlah sampel yang lebih besar untuk mendapatkan hasil dan kesimpulan yang layak digeneralisasi. Penelitian tentang pengaruh nudge dengan pendekatan norm juga perlu dilakukan pada kelompok target 
yang berbeda, seperti kelompok usia anak-anak ataupun orang tua, atau pada lokasi yang berbeda untuk memperoleh data yang lebih lengkap tentang perilaku membaca.

Norma subjektif memainkan peranan penting dalam membangun perilaku membaca remaja di Kabupaten Barru. Oleh karena itu, untuk meningkatkan budaya membaca masyarakat, khususnya remaja di Kabupaten Barru, Pemerintah Daerah Kabupaten Barru sebaiknya memfokuskan kebijakan pada pembangunan norma masyarakat yang mendukung berlangsungnya pengembangan budaya mem-baca. Upaya ini juga bisa saja diterapkan oleh pemerintah dari daerah lain, namun upaya pengujian faktor mana yang paling ber-pengaruh terhadap perilaku membaca masyarakat di daerah tersebut tetap harus dilakukan sebelumnya. Cremin, Mottram, Collins, Powell, dan Safford (2009) mengemukakan bahwa peran guru di sekolah, dan orang tua di rumah juga memainkan peran yang sangat penting dalam membangun budaya membaca anak dan remaja. Oleh karena itu dibutuhkan penelitian lebih lanjut tentang perilaku membaca yang melibatkan dua faktor tersebut.

\section{Daftar Pustaka}

Ajzen, I. (1991). The theory of planned behavior. Organizational behavior and human decision processes, 50(2), 179-211. doi: 10.1016/07495978(91)90020-T

Aldrovandi, S., Brown, G. D. A., \& Wood, A. M. (2015). Social norms and rank based nudging: Changing willingness to pay for healthy food. Journal of Experimental Psychology: Applied, 21(3), 242-254. doi: 10.1037/xap0000048

Alvermann, D. E. (2001, October 30). Effective literacy instruction for adolescents. Executive summary and paper commissioned by the National Reading Conference. Chicago, IL: National Reading Conference. Diunduh dari https://www.literacyresearchassociation.org /assets/docs/Websitedocs/alverwhite2.pdf

Berkowitz, A. D. (2004). An overview of the social norms approach. In L Lederman, L Stewart, F Goodhart \& L Laitman (Eds). Changing the culture of college drinking: A socially situated health communication campaign (193-214). New York: Hampton Press.

Chern, L. (2017, May 22). Nudging towards social change: The application of psychology and behavioral economics in promoting responsible consumption. Retrieved from http://scholarship.claremont.edu/cmc_theses $/ 1641$

Clark, C. \& Phythian-Sence, C. (2008, July 20). Interesting choice: The (relative) importance of choice and interest in reader engagement. Retrieved from https://lemosandcrane.co.uk/resources/NLT \%20-\%20Interesting\%20choice.pdf
Clark, C., \& Rumbold, K. (2006, November 1). Reading for pleasure a research overview. Retrieved from https://literacytrust.org.uk/researchservices/research-reports/reading-pleasureresearch-overview/

Cremin, T., Mottram, M., Collins, F., Powell, S. \& Safford, K. (2009). Teachers as readers: Building communities of readers 2007-08 executive summary. 43(1), 11-19. doi: 10.1111/j.1741-4369.2009.00515.x

Egan, M. (2013). Nudge database v1. 2. University of Stirling. Diakses dari https://www. stir. ac. uk/media/schools/management/documents/e conomics/Nudge\% 20Database, 201.

Fishbein, M., \& Ajzen, I. (1975). Belief, attitude, intentions and behavior: An introduction to theory and research. California: AddisonWesley Publishing Company, Inc.

Fishbein, M., \& Ajzen, I. (2005). Attitudes, personality, and behaviour. New York: OpenUniversity Press.

Handayani, R. (2008). Membangkitkan the power of library networking melalui pengembangan perpustakaan sebagai telecenter penyebaran informasi dan pengetahuan terkemuka. Visi Pustaka, 10(3).

Hansen, P. G. (2016). The definition of nudge and libertarian paternalism: Does the hand fit the glove?. European Journal of Risk Regulation, 7(1), 155-174. doi: $10.1017 / \mathrm{s} 1867299 \times 00005468$

Hapsari, M. I. (2009). Analisis sistemik penyelenggaraan taman bacaan masyarakat di kabupaten semarang. Andargogi-Jurnal PNFI, 1. Diunduh dari http://www.pustakaindonesia.org.

Miller, T., \& McFarland, C. (1991). When social comparison goes awry: The case of pluralistic ignorance. In J. Suls \& T. A. Wills (Eds.) Social Co mparison: Contem-porary Theory and Research (ch. 11). United States: Lawrence Erlbaum Associates, Inc

Moore, D. W., Bean, T. W., Birdyshaw, D., \& Rycik, J. A. (1999). Adolescent literacy: A position statement. Journal of Adolescent \& Adult Literacy, 43(1), 97-112.

Nadlir, M. (2018, 23 Maret). Per hari, rata-rata orang Indonesia hanya baca buku kurang dari sejam. Diunduh dari https://nasional.kompas.com/read/2018/03 /26/14432641/per-hari-rata-rata-orangindonesia-hanya-baca-buku-kurang-darisejam.

Perpustakaan Nasional. (2015). Profil per-pustakaan umum provinsi \& kabupaten/kota seIndonesia. Jakarta, DKI. Diunduh dari http://perpusnas.go.id/BukuElektronikAdd.a spx?id=54

Rivis, A., \& Sheeran, P. (2003). Descriptive norms as an additional predictor in the theory of planned behaviour: A meta analysis. Current Psychology. 22(3), 218-233. doi: 
10.1007/s12144-003-1018-2

Rossa, V. (2018, 21 Februari). Miris, minat baca masyarakat Indonesia hanya 0,01 persen. Diunduh dari https://www.suara.com/lifestyle/2018/02/2 $1 / 173000 /$ miris-minat-baca-masyarakatindonesia-hanya-001-persen

Santrock, J. W. (2003). Adolescence: perkembangan remaja. Jakarta: Penerbit Erlangga

Schultz, W. P., Khazian, A. M., \& Zaleski, A. C. (2008). Using normative social influence to promote conservation among hotel guests. Social influence, 3(1), 4-23. doi: 10.1080/15534510701755614

Schultz, P. W., Nolan, J. M., Cialdini, R. B., Goldstein, N.
J., \& Griskevicius, V. (2007). The constructive, destructive, and reconstructive power of social norms. Psychological science, 18(5), 429-434. doi: $10.1177 / 1745691617693325$

Terry, D. J., \& Hogg, M. A. (2000). Attitudes, behavior, and social context: the role of norms and group membership. New York: Psychology Press.

Thaler, R. \& Sunstein, C. (2008). Nudge. London: Yale University Press.

Wu, Y. \& Samuels, S. J. (2004). How the amount of time spent on independent readingaffects reading achievement: A response to the national reading panel. Retrieved from http://citeseerx.ist.psu.edu/viewdoc/downlo ad?doi=10.1.1.539.9906\&rep=rep1\&type=pdf 